\title{
Analisis Kesiapan Digitalisasi Sekolah Jenjang SMP di Kabupaten Sumbawa Barat
}

\author{
Hasanuddin ${ }^{1 *}$, Puryadi ${ }^{1}$, Agus Jayadi ${ }^{1}$ \\ 1 Universitas Cordova, Indonesia \\ *Korespondensi: hasanuddin*@undova.ac.id
}

\begin{tabular}{|c|c|}
\hline & \multirow{8}{*}{ 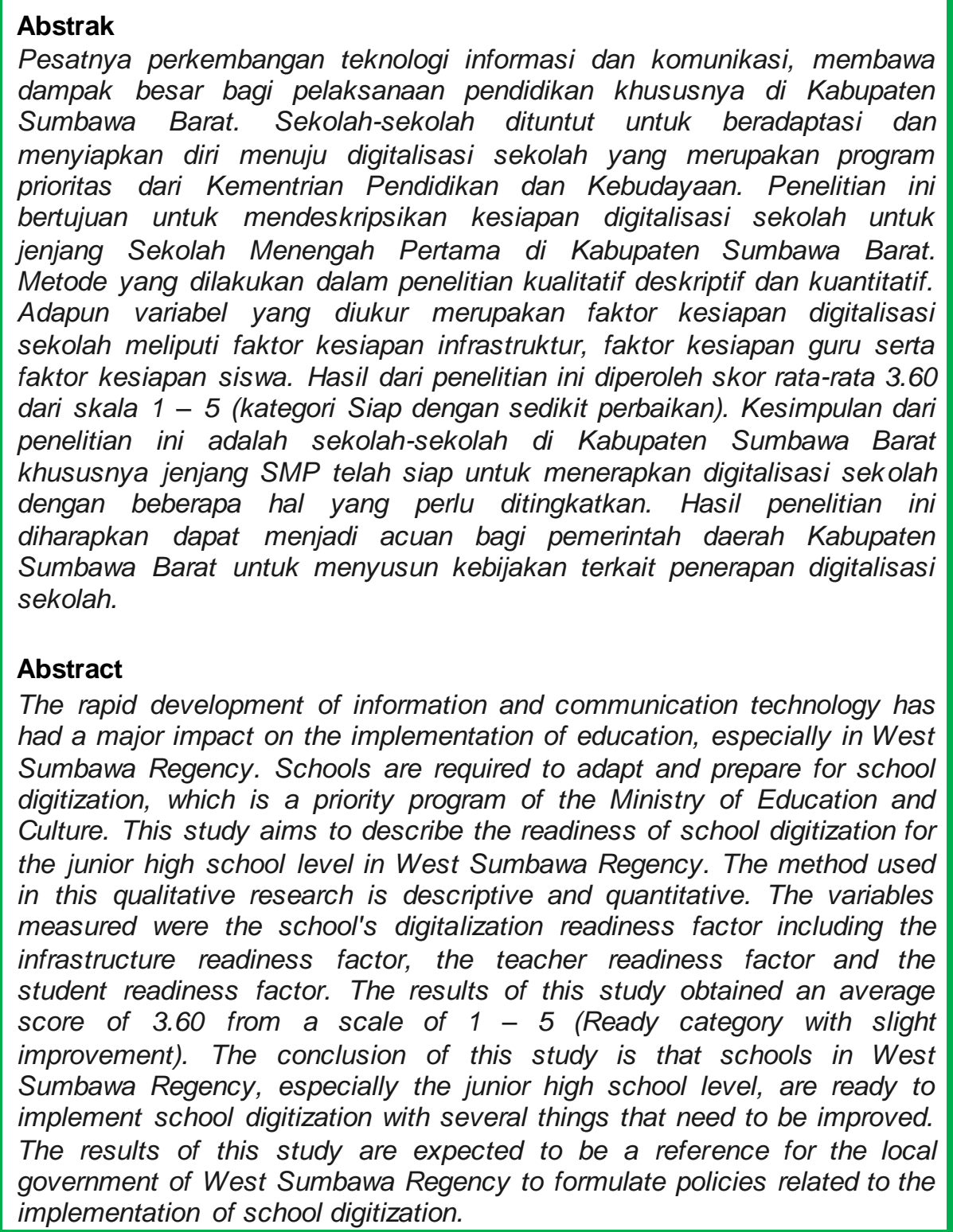 } \\
\hline & \\
\hline & \\
\hline & \\
\hline & \\
\hline & \\
\hline & \\
\hline & \\
\hline
\end{tabular}




\section{Pendahuluan}

Pendidikan menjadi wahana strategis untuk mengupayakan pen gembangan potensi tiap individu meraih kehidupan yang baik melalui berbagai nilai pada proses belajarnya (Hidayat \& Sari, 2019). Seiring perkembangan Teknologi Informasi dan Komunikasi (TIK) terutama dalam era Revolusi Industri 4.0, membawa perubahan besar dan dinamika dalam pelaksanaan dunia pendidikan. Kementrian Komunikasi dan Informatika Republik Indonesia bekerjasama dengan Kementrian Pendidikan dan Kebudayaan Republik Indonesia melakukan upayaupaya strategis untuk penerapan digitaliasi sekolah. Digitalisasi sekolah (Dewanti, 2020)adalah sebuah konsekuensi logis dari perubahan zaman. Melalui perubahan zaman itu pula, nilai adaptasi untuk bisa menguasai ilmu pengetahuan dan teknologi menjadi mutlak dibutuhkan. Termasuk pemanfaatan terobosan perkembangan teknologi informasi dalam proses belajar dan pengajaran sangat mutlak dibutuhkan baik selama pandemi maupun psca pandemi covid-19 yang melanda dunia dan Indonesia (Hermawansyah, 2021).

Pemerintah telah mengadopsi TIK dalam bingkai kebijakan pendidikan dan kurikulum nasional. Jenis keterampilan baru yang dibutuhkan sebagian besar didorong oleh pertumbuhan pesat informasi dalam repositori di seluruh dunia. Akibatnya, siswa perlu mengembangkan literasi informasi dan keterampilan terkait lainnya untuk mencari informasi dari sumber-sumber yang tak terbatas. Pada saat yang sama, kemajuan TIK tumbuh dengan cepat. Jika kemajuan baru dalam TIK ini dimanfaatkan untuk pendidikan, tentunya siswa maupun guru membutuhkan keahlian baru. Untuk itu diperlukan strategi implementasi dan pengembangan profesional yang komprehensif. Strategi impelementasi dan pengembangan profesional di bidang TIK harus mengacu pada kegiatan belajar dan mengajar. Indikator-indikator yang harus dikembangkan adalah: indikator akses, indikator output, dan indikator dampak. Kebijakan yang terarah dan sistematis dapat mengacu pada level Sekolah Berbasis TIK, yaitu: Perintis, Dasar, Menengah, dan Mapan, dimana pada masing-masing level ditinjau dari faktor: infrastruktur, sumber daya manusia, konten, pembelajaran, serta kebijakan dan program(Fitriyadi, 2013).

Dalam penelitian terdahulu (Zubaidah, 2016), menjelaskan bahwa untuk menghadapi dunia digital, aspek literasi digital harus menjadi prioritas utama untuk dikejar. Literasi digital menjadi keterampilan yang sangat diperlukan untuk dikuasai peserta didik sebagai generasi pemimpin masa mendatang. Dalam penelitian ini kesiapan sekolah dalam penerapan literasi digital akan diukur dan dianalisis agar dapat menjadi bahan pertimbangan dalam penerapan digitalisasi sekolah. Menurut (Amarulloh et al., 2019) adanya pengaruh digitalisasi penggunaan smartphone dalam pembelajaran serta menurut (Hijazi \& Alnatour, 2021) pembelajaran online dapat membantu daya pikir anak menjadi lebih kritis, sejalan dengan (Muhson, 2010) bahwa pembelajaran TIK memberikan kreatifitas anak dalam berfikir untuk mengikuti perkembangan zaman ini. Hal ini perlu ditindaklanjuti agar bisa diimplementasikan dalam suatu program digitaliasi sekolah. Dalam penelitian lainnya (Efendi, 2018) disebutkan bahwa revolusi pembelajaran berbasis digital harus bisa mendukung siswa belajar aktif agar kualitas belajar mengajar meningkat, serta menurut (Murhadi, 2019) bahwa salah satu strategi untuk menerapkan digitalisasi sekolah melalui pengembangan website dan layanan sekolah berbasis teknologi informasi. 
Kesiapan digitalisasi sekolah di Sumbawa Barat menjadi hal yang penting untuk diteliti mengingat perkembangan zaman yang semakin meningkat dalam pemanfaatan teknologi dan informasi. Terebih lagi dalam masa pandemik covid 19 saat ini, pemanfaatan teknologi informasi dalam sistem pembelajaran di sekolah menjadi sangat penting. Analisis kesiapan digitalisasi sekolah menjadi hal yang penting untuk diteliti terutama dari sisi sumber daya manusia dan infrastruktur yang tesedia.

Dinas Pendidikan dan Kebudayaan Kabupaten Sumbawa Barat Provinsi Nusa Tenggara Barat telah berupaya untuk merealisasikan program-program peningkatan kualitas pendidikan khususnya di Bidang Pendidikan Sekolah Mengah Pertama (SMP). Tantangan yang dihadapi saat ini adalah kesiapan sekolah u ntuk memasuki digitalisasi sekolah sehingga proses pendidikan yang dilaksanakan dapat berjalan mudah, lancar dan baik melalui pemanfaatan bidang TIK. Terbatasnya infrastruktur yang ada di sekolah, terbatasnya kemampuan para guru dan siswa dalam penerapan teknologi informasi dan komunikasi serta serta terbatasnya adaptasi sekolah memasuki dunia digital merupakan hal yang perlu dipastikan oleh Dinas Pendidikan dan Kebudayaan Kabupaten Sumbawa Barat dalam penerapan digitalisasi sekolah. Untuk itu, diperlukan suatu kajian terkait analisis kesiapan sekolah di Kabupaten Sumbawa Barat khususnya tingkat Sekolah Menengah Pertama terkait kesiapan digitalisasi sekolah. Hasil penelitian ini diharapkan dapat menjadi acuan bagi pemerintah daerah khususnya Dinas Pendidikan dan Kebudayaan Sumbawa Barat dalam menyusun strategi kebijakan penerapan digitalisasi sekolah khususnya pada jenjang Sekolah Menengah Pertama.

\section{Metode Penelitian}

Penelitian ini bertujuan untuk mendeskripsikan kesiapan digitalisasi sekolah jenjang Sekolah Menengah Pertama di Kabupaten Sumbawa Barat. Menurut (Sugiyono, 2010) dan (Uhyat, 2013) Jenis penelitian yang digunakan adalah penelitian kualitatif deskriptif dan kuantitatif. Data penelitian ini diambil dengan menggunakan kuisioner yang diberikan kepada setiap sampel penelitian. Berikut ini began alur penelitian.

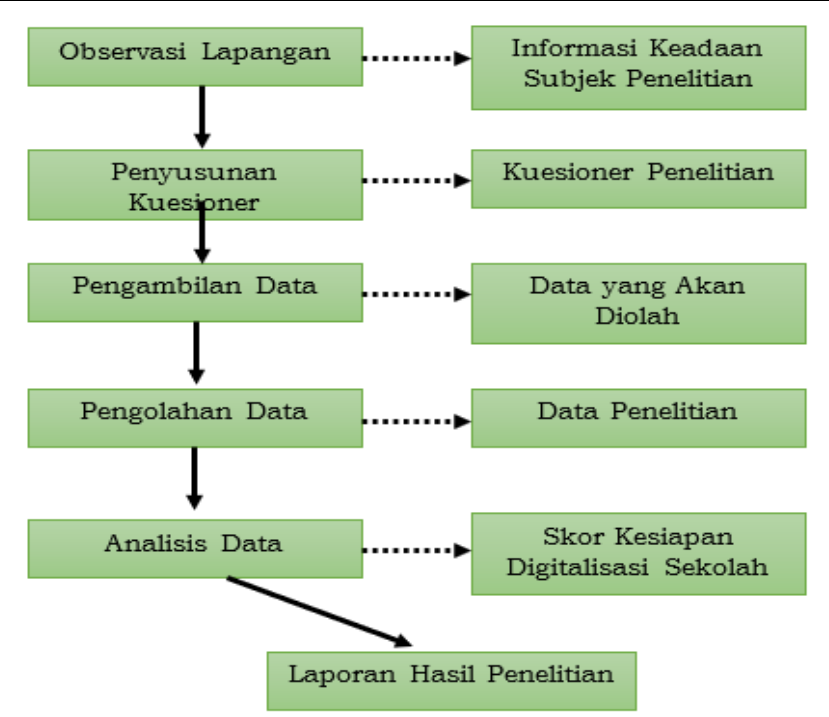

Gambar 1. Bagan Alur Penelitian 
Populasi dalam penelitian ini yaitu seluruh SMP Negeri yang ada di Kabupaten Sumbawa Barat. Penentuan sampelnya menggunakan teknik Clusster Sampling (Area Sampling). Sehingga didapatkan jumlah sampel 115 sampel yang terdiri dari 26 Kepala Sekolah dan 89 guru. Hasil dari penelitian yang didapatkan berdasarkan jawaban sampel kemudian dianalisis dengan membaginya menjadi beberapa kriteria. Kriteria dalam suatu penelitian dianggap penting karena dijadikan kesepakatan dalam penilaian. data yang diperoleh dianalisis menggunakan model e-learning readiness yang dikemukakan oleh (Aydin \& Tasci, 2005). Skala penilaian berupa empat kategori yaitu (1) Siap dan penerapan dapat dilaksanakan (2) Siap tetapi membutuhkan sedikit peningkatan (3) Tidak siap dan membutuhkan sedikit peningkatan (4) Tidak siap dan membutuhkan banyak peningkatan.

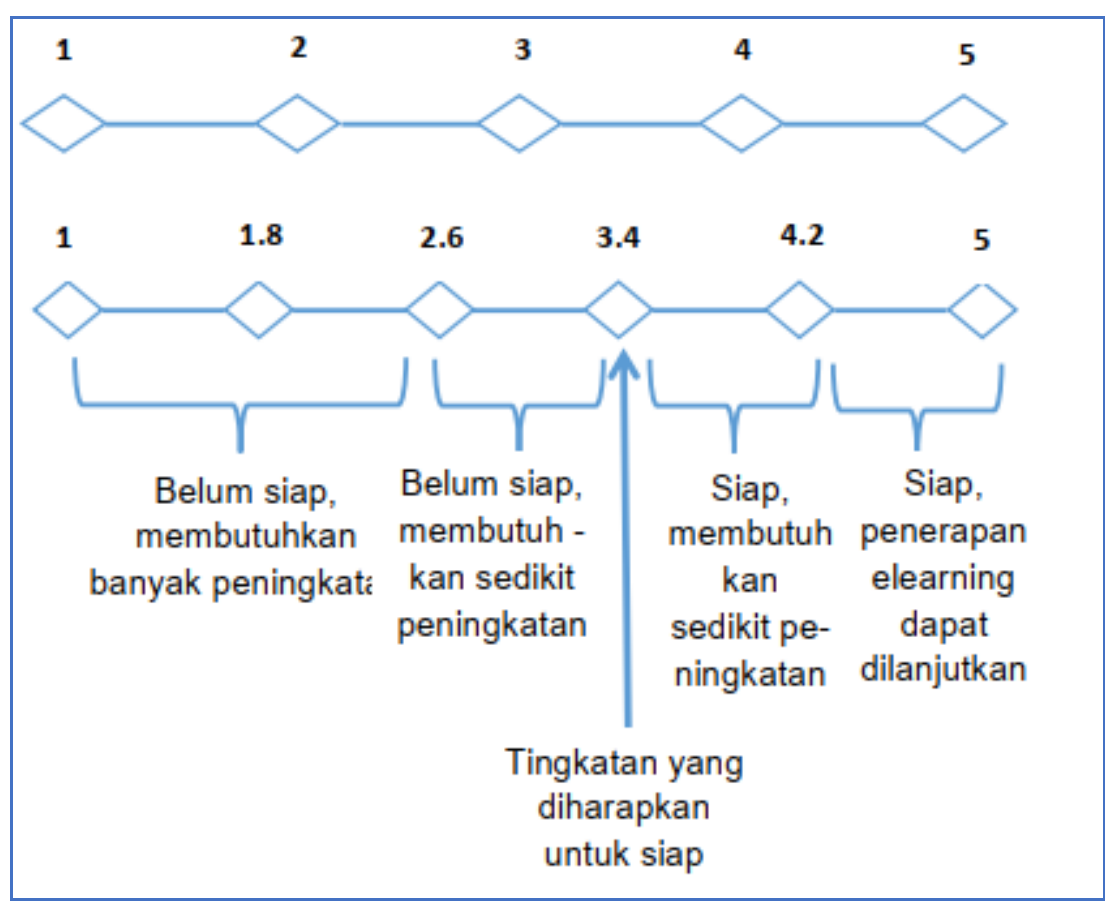

Gambar 2. Skala penilaian (Aydin \& Tasci, 2005).

\section{Hasil}

Data pokok peserta didik tahun ajaran 2020/2021 Semester Genap menunjukkan bahwa jumlah Sekolah Menengah Pertama (SMP) di Kabupaten Sumbawa Barat sebanyak 36 yang tersebar pada 8 kecamatan dengan rincian pada Tabel 1.

Tabel 1. Jumlah Sekolah Menengah Pertama (SMP)

\begin{tabular}{clccc}
\hline No. & Kecamatan & Jumlah & Negeri & Swasta \\
\hline 1. & Taliwang & 10 & 7 & 3 \\
\hline 2. & Seteluk & 5 & 5 & 0 \\
\hline 3. & Brang Rea & 4 & 4 & 0 \\
\hline 4. & Poto Tano & 6 & 6 & 0 \\
\hline 5. & Sekongkang & 4 & 3 & 1 \\
\hline 6. & Maluk & 3 & 1 & 2 \\
\hline 7. & Jereweh & 2 & 2 & 0 \\
\hline 8. & Brang Ene & 2 & 2 & 0 \\
\hline \multicolumn{2}{l}{ Kab. Sumbawa Barat } & $\mathbf{3 6}$ & $\mathbf{3 0}$ & $\mathbf{6}$ \\
\hline
\end{tabular}


Dari data pada tabel di atas dapat diketahui bahwa jumlah populasi dalam penelitian ini adalah 36 Sekolah. Kemudian dari jumlah populasi tersebut dilakukan sampling jumlah sekolah/kepala sekolah sebanyak 26 sample dan guru sebanyak 89 sample dengan distribusi pada Tabel 2.

Tabel 2. Jumlah Sample Kepala Sekolah dan Guru

\begin{tabular}{|c|l|c|c|c|}
\hline No. & Kecamatan & $\begin{array}{c}\text { Populasi } \\
\text { Sekolah }\end{array}$ & $\begin{array}{c}\text { Sampel } \\
\text { Sekolah/ } \\
\text { Kepala } \\
\text { Sekolah }\end{array}$ & $\begin{array}{c}\text { Sampel } \\
\text { Guru }\end{array}$ \\
\hline 1. & Taliwang & 10 & 8 & 24 \\
\hline 2. & Seteluk & 5 & 3 & 12 \\
\hline 3. & Brang Rea & 6 & 3 & 12 \\
\hline 4. & Poto Tano & 4 & 3 & 12 \\
\hline 5. & Sekongkang & 2 & 2 & 6 \\
\hline 6. & Maluk & 3 & 2 & 7 \\
\hline 7. & Jereweh & 2 & 2 & 6 \\
\hline 8. & Brang Ene & 4 & 3 & 10 \\
\hline & Jumlah & $\mathbf{3 6}$ & $\mathbf{2 6}$ & $\mathbf{8 9}$ \\
\hline
\end{tabular}

\section{Pembahasan}

\subsection{Kesiapan Faktor Infrastruktur}

Tujuan penggunaan kuesioner kepala sekolah ini adalah untuk mengetahui respon kepala sekolah terhadap kesiapan sekolah terkait infrastruktur dalam penerapan digitalisasi sekolah di Kabupaten Sumbawa Barat. Item soal pada kuesioner Kepala Sekolah berjumlah 8 soal yang diberi kode mulai dari Q1 sampai dengan Q8 dengan skor jawaban tertinggi yaitu lima (5) point sedangkan teren dah yaitu satu (1) point. Adapun daftar pertanyaan/soal terkait kesiapan faktor infrastruktur terlihat pada tabel 4.

Tabel 4. Daftar pertanyaan kesiapan faktor infrastruktur

\begin{tabular}{|c|c|c|}
\hline Kode & Daftar Pertanyaan & Pilihan Jawaban \\
\hline \multirow[t]{5}{*}{ Q1. } & \multirow{5}{*}{$\begin{array}{l}\text { Apakah Sekolah Bapak/lbu } \\
\text { menyediakan Komputer dengan } \\
\text { jumlah yang memadai, sehingga } \\
\text { siswa/guru dapat mengakses } \\
\text { komputer secara individual ? }\end{array}$} & Memadai semua (5) \\
\hline & & Sebagian besar memadai (4) \\
\hline & & Setengahnya memadai (3) \\
\hline & & Sebagian kecil memadai (2) \\
\hline & & Tidak memadai (1) \\
\hline \multirow[t]{5}{*}{ Q2. } & \multirow{5}{*}{$\begin{array}{l}\text { Apakah sekolah Bapak/lbu } \\
\text { menyediakan akses internet di } \\
\text { area/lingkungan sekolah? }\end{array}$} & Tersedia di seluruh area (5) \\
\hline & & Tersedia di sebagian besar area (4) \\
\hline & & Tersedia di setengah area (3) \\
\hline & & Tersedia di sebagian kecil area (2) \\
\hline & & Tidak tersedia \\
\hline \multirow[t]{3}{*}{ Q3. } & \multirow{3}{*}{$\begin{array}{l}\text { Apakah komputer di sekolah } \\
\text { Bapak/lbu terawat dengan baik } \\
\text { dan berkala? }\end{array}$} & Terawat baik dan berkala (5) \\
\hline & & Cukup terawat dan tidak berkala (4) \\
\hline & & Tidak terawat \\
\hline
\end{tabular}




\begin{tabular}{|c|c|c|}
\hline & & digunakan (3) \\
\hline & & Ada tapi dalam kondisi rusak (2) \\
\hline & & Belum ada komputer (1) \\
\hline \multirow[t]{5}{*}{ Q4. } & \multirow{5}{*}{$\begin{array}{l}\text { Apakah sekolah Bapak/lbu sudah } \\
\text { memiliki website profile sekolah } \\
\text { dan kontennya update? }\end{array}$} & Ada dan update berkala (5) \\
\hline & & Ada tapi kurang terupdate (4) \\
\hline & & Sempat ada tapi sudah tidak aktif (3) \\
\hline & & Sedang proses pengadaan (2) \\
\hline & & Belum ada \\
\hline \multirow[t]{5}{*}{ Q5. } & \multirow{5}{*}{$\begin{array}{l}\text { Apakah sekolah Bapak/lbu sudah } \\
\text { memiliki sistem aplikasi untuk tata } \\
\text { kelola sekolah dan manajemen } \\
\text { pembelajaran? }\end{array}$} & $\begin{array}{l}\text { Memiliki sistem aplikasi dan sudah } \\
\text { dimanfaatkan secara maksimal (5) }\end{array}$ \\
\hline & & $\begin{array}{l}\text { Memiliki sistem aplikasi tapi belum } \\
\text { termanfaatkan dengan optimal (4) }\end{array}$ \\
\hline & & $\begin{array}{l}\text { Baru memiliki sistem aplikasi tapi } \\
\text { belum dimanfaatkan (3) }\end{array}$ \\
\hline & & $\begin{array}{l}\text { Sedang pengadaan atau pembuatan } \\
\text { sistem aplikasi (2) }\end{array}$ \\
\hline & & Belum ada sistem aplikasi (1) \\
\hline \multirow[t]{5}{*}{ Q6. } & \multirow{5}{*}{$\begin{array}{l}\text { Apakah sekolah Bapak/lbu sudah } \\
\text { memiliki akun sosial media } \\
\text { (Facebook/Instagram/Channel } \\
\text { Youtube) dan aktif posting? }\end{array}$} & $\begin{array}{l}\text { Memiliki akun sosmed dan aktif/sering } \\
\text { posting (5) }\end{array}$ \\
\hline & & $\begin{array}{l}\text { Memiliki akun sosmed dan jarang } \\
\text { posting (4) }\end{array}$ \\
\hline & & $\begin{array}{l}\text { Baru memiliki akun sosmed beberapa } \\
\text { waktu lalu ( } 3 \text { ) }\end{array}$ \\
\hline & & $\begin{array}{l}\text { Sudah pernah memiliki akun sosmed } \\
\text { tapi sudah tidak aktif lagi (2) }\end{array}$ \\
\hline & & Belum ada akun sosmed (1) \\
\hline \multirow[t]{5}{*}{ Q7. } & \multirow{5}{*}{$\begin{array}{l}\text { Apakah sekolah Bapak/lbu sudah } \\
\text { memiliki perangkat pendukung } \\
\text { pembelajaran digital, misalnya: } \\
\text { LCD Projector, laptop kelas, dll? }\end{array}$} & Ada dan sering digunakan (5) \\
\hline & & Ada dan jarang digunakan (4) \\
\hline & & Ada dan belum digunakan (3) \\
\hline & & Ada tapi sudah tidak bisa digunakan (2) \\
\hline & & Belum ada (1) \\
\hline \multirow[t]{5}{*}{ Q8. } & \multirow{5}{*}{$\begin{array}{l}\text { Apakah sekolah Bapak/lbu sudah } \\
\text { menggunakan perangkat } \\
\text { pembelajaran digital, misalnya: e- } \\
\text { modul, slide materi, dll }\end{array}$} & Ada dan digunakan di semua mapel (5) \\
\hline & & $\begin{array}{l}\text { Ada dan digunakan sebagian besar } \\
\text { mapel (4) }\end{array}$ \\
\hline & & $\begin{array}{l}\text { Ada dan digunakan sebagian kecil } \\
\text { mapel (3) }\end{array}$ \\
\hline & & Ada dan jarang digunakan (2) \\
\hline & & Belum menggunakan (1) \\
\hline
\end{tabular}


Hasil analisis data yang didapatkan dari 26 responden yang telah mengisi kuesioner faktor kesiapan infrastruktur dapat dilihat pada tabel 5.

Tabel 5 . Hasil analisis kesiapan faktor infrastruktur

\begin{tabular}{cccccccccc}
\hline Item & Q1 & Q2 & Q3 & Q4 & Q5 & Q6 & Q7 & Q8 & $\begin{array}{c}\text { Rata- } \\
\text { rata }\end{array}$ \\
\hline $\begin{array}{c}\text { Rata- } \\
\text { rata }\end{array}$ & $\mathbf{3 . 3 8}$ & $\mathbf{3 . 4 2}$ & $\mathbf{4 . 3 5}$ & $\mathbf{3 . 3 1}$ & $\mathbf{2 . 6 2}$ & $\mathbf{4 . 0 4}$ & $\mathbf{4 . 2 3}$ & $\mathbf{3 . 4 2}$ & $\mathbf{3 . 6 0}$ \\
\hline
\end{tabular}

Indikator dalam faktor kesiapan infrastruktur ini menghasilkan nilai rata-rata 3,60 dimana masuk dalam kluster/kategori Siap Dengan Membutuhkan Sedikit Peningkatan $(3,4 \leq x \leq 4,1)$. Adapun item yang perlu peningkatan antara lain pada indikator (Q5) terkait dengan pemanfaatan sistem aplikasi untuk tata kelola sekolah dan manajemen pembelajaran. Dari hasil analisis data didapatkan bahwa skor rata-rata Q5 adalah 2,62 atau Sedang Pengadaan atau Pembuatan Sistem Aplikasi. Adapun indikator yang mendapatkan hasil tertinggi atau Siap, Penerapan Digitalisasi Sekolah Dapat Diajukan adalah indikator Q3 terkait komputer di sekolah terawat dengan baik dan berkala yang mendapatkan rata-rata skor 4,35 yaitu Cukup terawat dan tidak berkala. Item indikator lain yang mendapatkan nilai tinggi yaitu pada indikator Q7 terkait sekolah memiliki perangkat pendukung pembelajaran digital, misalnya: LCD Projector, laptop kelas, dll yang mendapatkan rata-rata skor 4,23 atau Ada dan jarang digunakan.

\subsection{Kesiapan Faktor Guru}

Tujuan penggunaan kuesioner guru ini yaitu untuk mengetahui respon gu ru terhadap kesiapan pendidik/guru dalam penerapan digitalisasi sekolah di Kabupaten Sumbawa Barat.Item pertanyaan/soal pada kuesioner Guru berjumlah 10 soal yang diberi kode mulai dari Q11 sampai dengan Q20 dengan skor jawaban tertinggi yaitu lima (5) point sedangkan terendah yaitu satu (1) point. Adapun daftar pertanyaan/soal terkait kesiapan faktor guru/pendidik terlihat pada tabel 6 .

Tabel 6. Daftar pertanyaan untuk kesiapan faktor guru/pendidik

\begin{tabular}{|c|c|c|}
\hline \multirow{6}{*}{$\frac{\text { Kode }}{\text { Q11. }}$} & Daftar Pertanyaan & Pilihan Jawaban \\
\hline & \multirow{5}{*}{$\begin{array}{l}\text { Apakah Bapak/lbu memiliki } \\
\text { laptop/smartphone dan dapat } \\
\text { mengoperasikannya secara mahir? }\end{array}$} & Memiliki dan sangat mahir (5) \\
\hline & & Memiliki dan cukup mahir (4) \\
\hline & & Tidak memiliki dan mahir (3) \\
\hline & & $\begin{array}{l}\text { Tidak memiliki dan tidak } \\
\text { mahir (2) }\end{array}$ \\
\hline & & Tidak mahir (1) \\
\hline \multirow[t]{5}{*}{ Q12. } & \multirow{5}{*}{$\begin{array}{l}\text { Apakah Bapak/lbu dapat mengakses } \\
\text { internet secara mudah? }\end{array}$} & Sangat mudah (5) \\
\hline & & Lumayan mudah (4) \\
\hline & & Mudah (3) \\
\hline & & Tidak mudah (2) \\
\hline & & Sangat tidak mudah (1) \\
\hline \multirow[t]{5}{*}{ Q13. } & \multirow{5}{*}{$\begin{array}{l}\text { Apakah Bapak/lbu mudah mencari } \\
\text { informasi di google, youtube, } \\
\text { facebook? }\end{array}$} & Sangat mudah (5) \\
\hline & & Lumayan mudah (4) \\
\hline & & Mudah (3) \\
\hline & & Tidak mudah (2) \\
\hline & & Sangat tidak mudah (1) \\
\hline \multirow[t]{2}{*}{ Q14. } & \multirow{2}{*}{$\begin{array}{l}\text { Apakah Bapak/lbu mahir untuk } \\
\text { menggunakan (zoom, google }\end{array}$} & Sangat mahir (5) \\
\hline & & Lumayan mahir (4) \\
\hline
\end{tabular}




\begin{tabular}{|c|c|c|}
\hline & \multirow[t]{2}{*}{$\begin{array}{l}\text { classroom, whatsapp, google drive, } \\
\text { dll? }\end{array}$} & $\begin{array}{l}\text { Mahir (3) } \\
\text { Tidak mahir (2) }\end{array}$ \\
\hline & & Sangat tidak mahir (1) \\
\hline \multirow[t]{5}{*}{ Q15. } & \multirow{5}{*}{$\begin{array}{l}\text { Apakah Bapak/lbu pernah } \\
\text { mengakses sumber belajar, seperti: } \\
\text { rumah belajar, ruang guru, zenius, } \\
\text { dll? }\end{array}$} & Sering (5) \\
\hline & & $\begin{array}{l}\text { Sempat pernah mengakses } \\
\text { (4) }\end{array}$ \\
\hline & & Pernah (3) \\
\hline & & $\begin{array}{l}\text { Tidak pernah, tapi pernah } \\
\text { dengar (2) }\end{array}$ \\
\hline & & Tidak pernah sama sekali( 1$)$ \\
\hline \multirow[t]{5}{*}{ Q16. } & \multirow{5}{*}{$\begin{array}{l}\text { Apakah Bapak/lbu bisa mengetik dan } \\
\text { menyunting file menggunakan laptop } \\
\text { atau smartphone? }\end{array}$} & Sangat bisa (5) \\
\hline & & Lumayan bisa (4) \\
\hline & & Bisa (3) \\
\hline & & Bisa sedikit-sedikit (2) \\
\hline & & Tidak bisa sama sekali (1) \\
\hline \multirow[t]{5}{*}{ Q17. } & \multirow{5}{*}{$\begin{array}{l}\text { Apakah Bapak/lbu pernah mengirim } \\
\text { tugas (Pekerjaan Rumah) melalui (e- } \\
\text { mail, whatsapp, google drive, dll? }\end{array}$} & Pernah dan sering (5) \\
\hline & & Lumayan sering (4) \\
\hline & & Sering (3) \\
\hline & & Tidak terlalu sering (2) \\
\hline & & Tidak pernah (1) \\
\hline \multirow[t]{5}{*}{ Q18. } & \multirow{5}{*}{$\begin{array}{l}\text { Apakah Bapak/lbu sering melakukan } \\
\text { pembelajaran secara daring (dalam } \\
\text { jaringan)? }\end{array}$} & Sangat sering (5) \\
\hline & & Lumayan sering (4) \\
\hline & & Sering (3) \\
\hline & & Tidak terlalu sering (2) \\
\hline & & Tidak pernah (1) \\
\hline \multirow[t]{5}{*}{ Q19. } & \multirow{5}{*}{$\begin{array}{l}\text { Apakah Bapak/lbu siap melakukan } \\
\text { pembelajaran daring menggunakan } \\
\text { teknologi informasi? }\end{array}$} & Sangat siap (5) \\
\hline & & Siap sekali (4) \\
\hline & & Siap (3) \\
\hline & & Belum siap (2) \\
\hline & & Tidak siap sama sekali (1) \\
\hline \multirow[t]{9}{*}{ Q20. } & \multirow{9}{*}{$\begin{array}{l}\text { Apakah Bapak/lbu merasa } \\
\text { pembelajaran secara daring interaktif } \\
\text { atau menyenangkan? }\end{array}$} & $\begin{array}{l}\text { Sangat interaktif atau } \\
\text { menyenangkan (5) }\end{array}$ \\
\hline & & $\begin{array}{l}\text { Kurang interaktif atau } \\
\text { menyenangkan (4) }\end{array}$ \\
\hline & & $\begin{array}{l}\text { Interaktif atau menyenangkan } \\
\text { (3) }\end{array}$ \\
\hline & & $\begin{array}{l}\text { Tidak interaktif atau tidak } \\
\text { menyenangkan (2) }\end{array}$ \\
\hline & & $\begin{array}{l}\text { Sangat tidak interaktif atau } \\
\text { tidak menyenangkan (1) }\end{array}$ \\
\hline & & $\begin{array}{l}\text { Kurang interaktif atau } \\
\text { menyenangkan (4) }\end{array}$ \\
\hline & & $\begin{array}{l}\text { Interaktif atau menyenangkan } \\
\text { (3) }\end{array}$ \\
\hline & & $\begin{array}{l}\text { Tidak interaktif atau tidak } \\
\text { menyenangkan (2) }\end{array}$ \\
\hline & & $\begin{array}{l}\text { Sangat tidak interaktif atau } \\
\text { tidak menyenangkan (1) }\end{array}$ \\
\hline
\end{tabular}


Hasil analisis data yang didapatkan pada kuesioner faktor kesiapan guru/pendidik dapat dilihat pada tabel 7.

Table 7. Hasil analisis kesiapan faktor guru/pendidik

\begin{tabular}{|c|c|c|c|c|c|c|c|c|c|c|c|}
\hline Item & Q11 & Q12 & Q13 & Q14 & Q15 & Q16 & Q17 & Q18 & Q19 & Q20 & $\begin{array}{c}\text { Rata- } \\
\text { rata }\end{array}$ \\
\hline $\begin{array}{c}\text { Rata- } \\
\text { rata }\end{array}$ & $\mathbf{3 . 7 6}$ & $\mathbf{4 . 0 2}$ & $\mathbf{4 . 0 8}$ & $\mathbf{3 . 7 3}$ & $\mathbf{3 . 2 2}$ & $\mathbf{3 . 5 8}$ & $\mathbf{3 . 8 3}$ & $\mathbf{3 . 4 9}$ & $\mathbf{3 . 6 2}$ & $\mathbf{3 . 6 4}$ & $\mathbf{3 . 7 0}$ \\
\hline
\end{tabular}

Indikator dalam aspek kesiapan pendidik/guru ini hampir semua siap dengan membutuhkan sedikit peningkatan $(3,4 \leq x \leq 4,1)$. Hanya saja perlu peningkatan pada indikator (Q15) terkait dengan akses sumber belajar seperti: rumah belajar, ruang guru, zenius, dan sumber-sumber belajar lainnya. Dari hasil analisis data didapatkan bahwa skor rata-rata Q15 adalah 3,22 atau pernah mengakses namun jarang diterapkan dalam sistem pembelajaran kepada siswa. Hal ini perlu ditingkatkan mengingat peran guru semakin penting dalam era digital saat in i sebagai resource linker. Guru tidak hanya mengajar, tetapi harus menguasai sumber-sumber belajar dari mana saja dan guru mampu mengarahkan siswa atau peserta didik untuk menemukan sumber-sumber belajar yang bermanfaat.

Indikator Q12 tentang kemudahan akses internat serta Q13 tentang kemudahan pencarian informasi melalui google, youtube serta facebook dikategorikan lumayan mudah. Guru dapat dengan lumayan mudah mengakses internet serta pencarian sumber informasi yang dibutuhkan melalui internet. Hal ini terlihat dari hasil analisis data dengan skor yang didapatkan masing-masing yaitu untuk Q12 adalah 4,02 sedangkan Q3 adalah 4 Skor ini masih dikategorikan siap dengan membutuhkan sedikit peningkatan.

Oleh karena itu, dapat diketahui bahwa rata-rata faktor kesiapan guru mencapai 3,70 atau dengan kategori : Siap dengan Membutuhkan Sedikit Peningkatan. Beberapa hal yang perlu ditingkatkan yaitu :

1. Kemampuan guru dalam menggunakan beberapa media belajar online seperti: zoom, google classroom, whatsapp serta google drive

2. Kemampuan guru untuk mengakses dan menerapkan penggunaan sumber belajar seperti: rumah belajar, ruang guru, zenius, dan sumber-sumber belajar lainnya

3. Kemampuan guru dalam melakukan pembelajaran dalam jaringan atau secara daring

\subsection{Kesiapan Faktor Siswa}

Tujuan penggunaan kuesioner ini yaitu untuk mengetahui tingkat kesiapan peserta didik/siswa dalam penerapan digitalisasi sekolah di Kabupaten Sumbawa Barat. Untuk mengukur kesiapan faktor peserta didik/siswa, responden yang digunakan adalah guru sebanyak 89 orang yang tersebar ke dalam beberapa sekolah yang mencakup delapan kecamatan di Kabupaten Sumbawa Barat. Adapun alasan pengisian kuisioner kesiapan sekolah terkait peserta didik/siswa yang diisi oleh guru siswa adalah Pertama, dalam masa pengumpulan data, siswa sedang proses ujian akhir semester dan dilanjutkan libur sekolah. Kedua, pertanyaan yang diajukan terkait dengan pertanyaan yang diajukan pada pendidik/guru. Item soal pada kuesioner faktor kesiapan peserta didik/siswa 
berjumlah 10 soal yang diberi kode mulai dari Q21 sampai dengan Q30 dengan skor jawaban tertinggi yaitu lima (5) point sedangkan terendah yaitu satu (1) point. Adapun daftar pertanyaan/soal terkait kesiapan faktor siswa/peserta didik terlihat pada tabel 8.

Tabel 8. Daftar pertanyaan untuk kesiapan faktor siswa

\begin{tabular}{|c|c|c|}
\hline Kode. & Daftar Pertanyaan & Pilihan Jawaban \\
\hline \multirow[t]{5}{*}{ Q21. } & \multirow{5}{*}{$\begin{array}{l}\text { Apakah siswa Bapak/lbu memiliki } \\
\text { Laptop/smartphone dan dapat } \\
\text { mengoperasikannya secara mahir? }\end{array}$} & Memiliki dan sangat mahir (5) \\
\hline & & Memiliki dan cukup mahir (4) \\
\hline & & Tidak memiliki dan mahir (3) \\
\hline & & Tidak memiliki dan tidak mahir (2) \\
\hline & & Tidak mahir (1) \\
\hline \multirow[t]{5}{*}{ Q22. } & \multirow{5}{*}{$\begin{array}{l}\text { Apakah Siswa Bapak/lbu dapat } \\
\text { mengakses internet secara mudah? }\end{array}$} & Sangat mudah (5) \\
\hline & & Lumayan mudah (4) \\
\hline & & Mudah (3) \\
\hline & & Tidak mudah (2) \\
\hline & & Sangat tidak mudah (1) \\
\hline \multirow[t]{5}{*}{ Q23. } & \multirow{5}{*}{$\begin{array}{l}\text { Apakah Siswa Bapak/lbu mudah } \\
\text { mencari informasi di google, youtube, } \\
\text { facebook? }\end{array}$} & Sangat mudah (5) \\
\hline & & Lumayan mudah (4) \\
\hline & & Mudah (3) \\
\hline & & Tidak mudah (2) \\
\hline & & Sangat tidak mudah (1) \\
\hline \multirow[t]{5}{*}{ Q24. } & \multirow{5}{*}{$\begin{array}{l}\text { Apakah Siswa Bapak/lbu mahir untuk } \\
\text { menggunakan (zoom, google } \\
\text { classroom, whatsapp, google drive, } \\
\text { dll? }\end{array}$} & Sangat mahir (5) \\
\hline & & Lumayan mahir (4) \\
\hline & & Mahir (3) \\
\hline & & Tidak mahir (2) \\
\hline & & Sangat tidak mahir (1) \\
\hline \multirow[t]{5}{*}{ Q25. } & \multirow{5}{*}{$\begin{array}{l}\text { Apakah Bapak/lbu pernah mengakses } \\
\text { sumber belajar, seperti: rumah } \\
\text { belajar, ruang guru, zenius, dll? }\end{array}$} & Sering (5) \\
\hline & & Sempat pernah mengakses (4) \\
\hline & & Pernah (3) \\
\hline & & $\begin{array}{l}\text { Tidak pernah, tapi pernah dengar } \\
\text { (2) }\end{array}$ \\
\hline & & Tidak pernah sama sekali( 1$)$ \\
\hline \multirow[t]{5}{*}{ Q26. } & \multirow{5}{*}{$\begin{array}{l}\text { Apakah Siswa Bapak/lbu bisa } \\
\text { mengetik dan mengerjakan pekerjaan } \\
\text { rumah (PR) menggunakan laptop atau } \\
\text { smartphone? }\end{array}$} & Sangat bisa (5) \\
\hline & & Lumayan bisa (4) \\
\hline & & Bisa (3) \\
\hline & & Bisa sedikit-sedikit (2) \\
\hline & & Tidak bisa sama sekali (1) \\
\hline \multirow[t]{5}{*}{ Q27. } & \multirow{5}{*}{$\begin{array}{l}\text { Apakah Siswa Bapak/lbu pernah } \\
\text { mengumpulkan Pekerjaan Rumah } \\
\text { (PR) melalui (e-mail, whatsapp, } \\
\text { google drive, dll? }\end{array}$} & Pernah dan sering (5) \\
\hline & & Lumayan sering (4) \\
\hline & & Sering (3) \\
\hline & & Tidak terlalu sering (2) \\
\hline & & Tidak pernah (1) \\
\hline \multirow[t]{5}{*}{ Q28. } & \multirow{5}{*}{$\begin{array}{l}\text { Apakah Siswa Bapak/lbu sering } \\
\text { mengikuti pembelajaran secara daring } \\
\text { (dalam jaringan)? }\end{array}$} & Sangat sering (5) \\
\hline & & Lumayan sering (4) \\
\hline & & Sering (3) \\
\hline & & Tidak terlalu sering (2) \\
\hline & & Tidak pernah (1) \\
\hline \multirow[t]{4}{*}{ Q29. } & \multirow{4}{*}{$\begin{array}{l}\text { Apakah Siswa Bapak/lbu siap } \\
\text { mengikuti pembelajaran daring } \\
\text { menggunakan teknologi informasi? }\end{array}$} & Sangat siap (5) \\
\hline & & Siap sekali (4) \\
\hline & & Siap (3) \\
\hline & & Belum siap (2) \\
\hline
\end{tabular}




\begin{tabular}{|c|c|c|}
\hline & & Tidak siap sama sekali (1) \\
\hline \multirow[t]{5}{*}{ Q30. } & \multirow{5}{*}{$\begin{array}{l}\text { Apakah Siswa Bapak/lbu merasa } \\
\text { pembelajaran secara daring interaktif } \\
\text { atau menyenangkan? }\end{array}$} & $\begin{array}{l}\text { Sangat interaktif } \\
\text { menyenangkan (5) }\end{array}$ \\
\hline & & $\begin{array}{ll}\text { Kurang interaktif } & \text { atau } \\
\text { menyenangkan (4) } & \end{array}$ \\
\hline & & Interaktif atau menyenangkan (3) \\
\hline & & $\begin{array}{lccc}\text { Tidak interaktif } & \text { atau } & \text { tidak } \\
\text { menyenangkan (2) } & & \\
\end{array}$ \\
\hline & & $\begin{array}{l}\text { Sangat tidak interaktif atau tidak } \\
\text { menyenangkan (1) }\end{array}$ \\
\hline
\end{tabular}

Hasil analisis data yang didapatkan pada kuesioner faktor kesiapan siswa dapat dilihat pada tabel 9.

Table 9. Hasil analisis kesiapan faktor siswa

\begin{tabular}{|c|c|c|c|c|c|c|c|c|c|c|c|}
\hline Item & Q21 & Q22 & Q23 & Q24 & Q25 & Q26 & Q27 & Q28 & Q29 & Q30 & $\begin{array}{c}\text { Rata- } \\
\text { rata }\end{array}$ \\
\hline $\begin{array}{c}\text { Rata- } \\
\text { rata }\end{array}$ & 4.10 & 4.03 & 3.84 & 2.96 & 2.87 & 3.31 & 3.10 & 2.94 & 3.15 & 3.24 & 3.35 \\
\hline
\end{tabular}

Indikator dalam aspek kesiapan peserta didik/siswa ini beberapa indikator item soal yang ditanyakan mendapatkan hasil kategori : Tidak siap dan dibutuhkan peningkatan. Beberapa item yang perlu ditingkatkan yaitu Q24, Q25, dan Q28. Q24 menunjukkan bahwa Siswa belum mahir dalam menggunakan media belajar online seperti zoom meeting/google meet, google classroom, google drive serta media-media pembelajaran lainnya. Selain itu Q25 siswa juga masih belum pernah mengakses beberapa sumber-sumber belajar online seperti rumah belajar, ruang guru, zenius serta sumber-sumber belajar online lainnya.

Sedangkan dari indikator item soal Q28 menunjukkan bahwa tidak terlalu sering mengikuti pembelajaran secara daring. Beberapa indikator item soal tersebut sangat penting dalam mendukung penerapan digitalisasi sekolah. Hal ini perlu untuk ditingkatkan penerapannya saat pembelajaran berlangsung. Peran guru menjadi sangat penting di sini dalam mengarahkan dan membimbing siswa atau peserta didiknya untuk lebih mahir dalam menggunakan media belajar online, menggunakan sumber belajar digital serta membiasakan siswa untuk dapat mengikuti pembelajaran secara daring. Berikut adalah tabel kategori yang didapatkan dari masing-masing indikator item soal yang ditanyakan terkait dengan kesiapan siswa dalam menerapkan digitalsisasi sekolah.

Indikator Q21 tentang Siswa memiliki laptop/smartphone dan dapat mengoperasikannya secara mahir, dikategorikan : Memiliki dan Cukup Mahir. Indikator lainnya yang mendapatkan hasil cukup tinggi adalah indikator Q22 terkait Siswa dapat mengakses internet secara mudah, dikategorikan : Lumayan Mudah. Sehingga, dapat diketahui bahwa rata-rata faktor kesiapan siswa mencapai 3,35 atau dengan kategori : Tidak Siap dengan Membutuhkan Sedikit Peningkatan. Beberapa hal terkait kemampuan Siswa yang perlu ditingkatkan yaitu :

1. Kemampuan Siswa dalam menggunakan zoom meeting/google meet, google classroom serta google drive

2. Kemampuan siswa untuk mengakses dan menggunakan sumber belajar seperti rumah belajar, ruang guru dan zenius 
3. Serta pembiasaan kepada siswa untuk mengikuti pembelajaran dalam jaringan

Kemampuan siswa dalam menggunakan zoom meeting/google meet, google classroom serta google drive perlu ditingkatkan. Hal ini merupakan indikator penting dalam mendukung penerapan digitalisasi sekolah dari sisi sumber daya manusia terutama siswa. Penggunaan media belajar ini perlu dibiasakan oleh Gun dengan sering menerapkan kegiatan belajar menggunakan zoom meeting/google meet, google classroom serta google drive. Berdasarkan hasil yang didapatkan dari instrumen penelitian pada kode daftar pertanyaan Q14 menunjukkan bahwa Guru mahir dalam menggunakan (zoom, google classroom, whatsapp, google drive, dll) dengan skor yang didapatkan yaitu 3,73. Hanya saja penerapannya dalam pembelajaran yang belum sering dilakukan bersama dengan siswa. Ini sesuai dengan hasil yang didapatkan pada kode pertanyaan Q28 yaitu mendapatkan skor 2,9 artinya Siswa belum terlalu sering dalam menggunakan media belajar seperti zoom meet/google meet, google classroom dan google drive. $\mathrm{Hal}$ serupa perlu ditingkatkan pada kemampuan siswa dalam mengakses sumbersumber belajar online dengan perlu melibatkan siswa untuk mengakses sumbersumber belajar online seperti rumah belajar, ruang guru dan zenius.

\section{Kesimpulan}

Berdasarkan hasil analisis data dapat disimpulkan bahwa Kesiapan Digitalisasi Sekolah di Kabupaten Sumbawa Barat untuk jenjang Pendidikan Sekolah Menengah Pertama dalam faktor kesiapan infrastruktur masuk dalam kluster/kategori : Siap dengan membutuhkan sedikit peningkatan, dengan skor rata-rata : 3,60 dari skala 1 - 5. Hasil yang sama diperoleh dalam faktor kesiapan pendidik/tenaga pendidik dimana masuk dalam kluster/kategori : Siap dengan membutuhkan sedikit peningkatan, dengan skor rata-rata : 3,70 dari skala 1 5. Sedangkan untuk faktor kesiapan peserta didik masuk dalam kluster/kategori : Tidak siap namun membutuhkan sedikit peningkatan, dengan skor rata-rata : 3,35 dari skala 1 - 5. Ketidaksempurnaan nilai pada masing-masing indikator menunjukkan bahwa indikator tersebut masih perlu diperhatikan dan ditingkatkan baik untuk faktor kesiapan infrastruktur, faktor kesiapan pendidik/guru maupun faktor kesiapan peserta didik/siswa.

Dari hasil penelitian yang didapatkan, peneliti menyarankan kepada pemerintah daerah khususnya Dinas Pendidikan dan Kebudayaan (DIKBUD) Sumbawa Barat untuk menyediakan dan menerapkan tata kelola Teknologi Informasi dan Komunikasi (TIK) pada jenjang Sekolah Menengah Pertama di Kabupaten Sumbawa Barat baik meliputi e-administrasi sekolah maupun epembelajaran sekolah. Selain itu juga diharapkan Dikbud Sumbawa Barat untuk menyelenggarakan pelatihan bagi guru dan siswa pada jenjang Sekolah Menengah Pertama di Kabupaten Sumbawa Barat terkait pemanfaatan aplikasi pembelajaran untuk meningkatkan kesiapan sekolah dalam penerapan digitalisasi sekolah. Aplikasi pembelajaran tersebut terbagi dalam kategori : aplikasi tatap muka virtual (google meet/zoom meeting), aplikasi e-pembelajaran (google classroom/moodle CMS) serta aplikasi pendukung pembelajaran (google drive, google calender, dII). 


\section{Daftar Pustaka}

Amarulloh, A., Surahman, E., \& Meylani, V. (2019). Digitalisasi Dalam Proses Pembelajaran Dan. BIOEDUKASI Jurnal Pendidikan Biologi Universitas Muhammadiyah Metro, June, 8. https://doi.org/10.24127/bioedukasi.v11i1.2815

Aydin, C. H., \& Tasci, D. (2005). Measuring readiness for e-learning: Reflections from an emerging country. Educational Technology and Society, 8(4), 244257.

Dewanti, A. K. (2020). Efektifitas Program Digitalisasi Sekolah. Arsip Publikasi IImiah Biro Administrasi Akademik, $O(0)$. http://researchreport.umm.ac.id/index.php/API-BAA/article/view/4096

Efendi, N. M. (2018). Revolusi Pembelajaran Berbasis Digital (Penggunaan Animasi Digital Pada Start UP Sebagai Metode Pembelajaran Siswa Belajar Aktif). Habitus: Jurnal Pendidikan, Sosiologi, \& Antropologi, 2(2), 173-182. https://doi.org/10.20961/HABITUS.V212.28788

Fitriyadi, H. (2013). Integrasi Teknologi Informasi Komunikasi dalam Pendidikan: Potensi Manfaat, Masyarakat Berbasis Pengetahuan, Pendidikan Nilai, Strategi Implementasi dan Pengembangan Profesional. Jurnal Pendidikan Teknologi Dan Kejuruan, 21(3), 1-1. https://doi.org/10.21831/JPTK.V2113.3255

Hermawansyah, H. (2021). Manajemen Lembaga Pendidikan Sekolah Berbasis Digitalisasi di Era Covid -19. Fitrah: Jurnal Studi Pendidikan, 12(1), 27-46. https://doi.org/10.47625

Hidayat, W., \& Sari, V. T. A. (2019). Kemampuan Berpikir Kritis Matematis dan Adversity Quotient Siswa SMP. Jurnal Elemen, 5(2), 242. https://doi.org/10.29408/jel.v5i2.1454

Hijazi, D., \& Alnatour, A. (2021). Online learning challenges affecting students of english in an efl context during covid-19 pandemic. International Journal of Education and Practice, 9(2), 379-395. https://doi.org/10.18488/journal.61.2021.92.379.395

Muhson, A. (2010). Pengembangan Media Pembelajaran Berbasis Teknologi Informasi. Jurnal Pendidikan Akuntansi Indonesia, 8(2). https://doi.org/10.21831/jpai.v8i2.949

Sekolah Melalui Pengembangan Website dan Layanan Sekolah Berbasis Teknologi Informasi Murhadi, D. (2019). Digitalisasi Sekolah Melalui Pengembangan Website dan Layanan Sekolah Berbasis Teknologi Informasi. INTEK: Jurnal Informatika Dan Teknologi Informasi, 2(2), 62-69. https://doi.org/10.37729/INTEK.V2I2.567

Sugiyono. (2010). Metode Penelitian Pendidikan Pendekatan Kuantitatif, kualitatif, dan $R \& D$. Alfabeta.

Uhyat, H. (2013). Metode Penelitian Pendidikan Pendekatan Kuantitaif, Kualitatif, dan R\&D. 283-393.

Zubaidah, S. (2016). Keterampilan Abad Ke-21: Keterampilan Yang Diajarkan Melalui Pembelajaran. Seminar Nasional Pendidikan Dengan Tema "Isu-Isu Strategis Pembelajaran MIPA Abad 21, Desember, 1-17. 